\title{
New records of the East Mediterranean Lachesana (Aranei: Zodariidae), with description of a new species
}

\author{
Новые нахожкки восточносредиземноморских Lachesana \\ (Aranei: Zodariidae), с описанием нового вида
}

\author{
Recep Sulhi Özkütük ${ }^{1}$, Ersen Aydın Yağmur², Salih Gücel ${ }^{3,4}$, \\ Sepideh Shafaie ${ }^{5}$, Özge Özden ${ }^{3,4}$, Kadir Boğaç Kunt ${ }^{1,6}$ \\ Р.С. Озкютюк ${ }^{1}$ Э.Ф. Ягмур ${ }^{2}$, С. Гюджекь ${ }^{3,4}$, С. Шафаие \\ O. Озден ${ }^{3,4}$, К.Б. Кунт ${ }^{1,6}$
}

\footnotetext{
${ }^{1}$ Department of Biology, Faculty of Science, Eskişehir Technical University, TR-26470 Eskişehir, Turkey

${ }^{2}$ Alaşehir Vocational School, Celal Bayar University, TR-45600 Alaşehir, Manisa, Turkey

${ }^{3}$ Herbarium and Natural History Museum, University of Near East, Nicosia, Cyprus

${ }^{4}$ Department of Landscape Architecture, Faculty of Architecture, University of Near East, Nicosia, Cyprus

${ }^{5}$ Department of Biology, Faculty of Science, Ferdowsi University of Mashhad, Mashhad, Iran

${ }^{6}$ Wildlife Research Institute, Taşkent, Kyrenia, Cyprus
}

KEY WORDS: Araneae, Anatolia, Turkey, Cyprus, distribution, Lachesaninae, spider.

КЛЮЧЕВЫЕ СЛОВА: Araneae, Анатолия, Турция, Кипр, распространение, Lachesaninae, паук.

ABSTRACT. A new species Lachesana bayramgocmeni sp.n. is described based on both sexes from Cyprus. The new species is compared in detail with $L$. blackwalli (O. Pickard-Cambridge, 1872). New data on the distribution of L. blackwalli in Turkey and $\mathrm{Cy}-$ prus are presented.

How to cite this article: Özkütük R.S., Yağmur E.A., Gücel S., Shafaie S., Özden Ö., Kunt K.B. 2020. New records of the East Mediterranean Lachesana (Aranei: Zodariidae), with description of a new species // Arthropoda Selecta. Vol.29. No.3. P.334-338. doi: 10.15298/arthsel. 29.3.06

РЕЗЮМЕ. Описан из Кипра новый вид пауков Lachesana bayramgocmeni sp.n. на основе обоих полов. Новый вид близок к L. blackwalli (O. PickardCambridge, 1872), оба вида подробно сравниваются. Представлены новые данные о распространении L. blackwalli в Турции и на Кипре.

\section{Introduction}

The subfamily Lachesaninae Jocqué, 1991 currently includes three genera: Antillorena Jocqué, 1991; Lachesana Strand, 1932 and Lutica Marx, 1891 [Jocqué, 1991]. The subfamily is known in the Neotropics (Antillorena), Nearctic (Lutica) and West Palaearctic (Lachesana). The most characteristic feature of the subfamily is that the anterior spinnerets are long and retractable.

The present study has started from the examination of several Lachesana males, collected in the Beşparmak Mountains (Cyprus), in the course of regional spider fauna investigation. During the examination of these males, we noticed that they differ by the shape of the palp from L. blackwalli (O. Pickard-Cambridge, 1872), a species previosuly reported from the island. Our suspicions that this Lachesana from Cyprus could belong to a new species were confirmed, when we found a distinguishable conspecific female.

The aim of this study is to describe a new Lachesana species from Cyprus. The comparative illustrations showing the copulatory organs and the somatic structures of both the new species and the most closely related L. blackwalli are provided.

\section{Material and Methods}

The specimens were preserved in $70 \%$ ethanol. Digital images of the copulatory organs were obtained using the Leica DFC295 digital camera attached to a Leica S8AP0 stereomicroscope. From 5 to 15 photographs were taken in different focal planes and combined using "CombineZP" image stacking software.

All measurements are given in $\mathrm{mm}$. Terminology for the body measurements, copulatory organ structures and spination are after Jocqué [1991]. The following abbreviations were used in the text: ALE - anterior lateral eyes; AME anterior median eyes; PLE — posterior lateral eyes; PME posterior median eyes; $\mathrm{Ta}$ - tarsus; $\mathrm{Mt}$ - metatarsus, $\mathrm{T}$ tibia; $\mathrm{P}$ - patella; $\mathrm{F}$ - femur; $\mathrm{d}$ - dorsal; $\mathrm{p}$ - prolateral; $\mathrm{r}$ - retrolateral; $\mathrm{v}$ - ventral; $\mathrm{CO}$ - conductor; E - embolus, RTA - retrolateral tibial apophysis; CHNM - Cyprus Herbarium \& Natural History Museum, Near East University, Nicosia, Cyprus; ETZM - Eskişehir Technical University Zoology Museum, Eskişehir, Turkey; ZMMU — Zoological Museum of the Moscow State University, Moscow, Russia. 


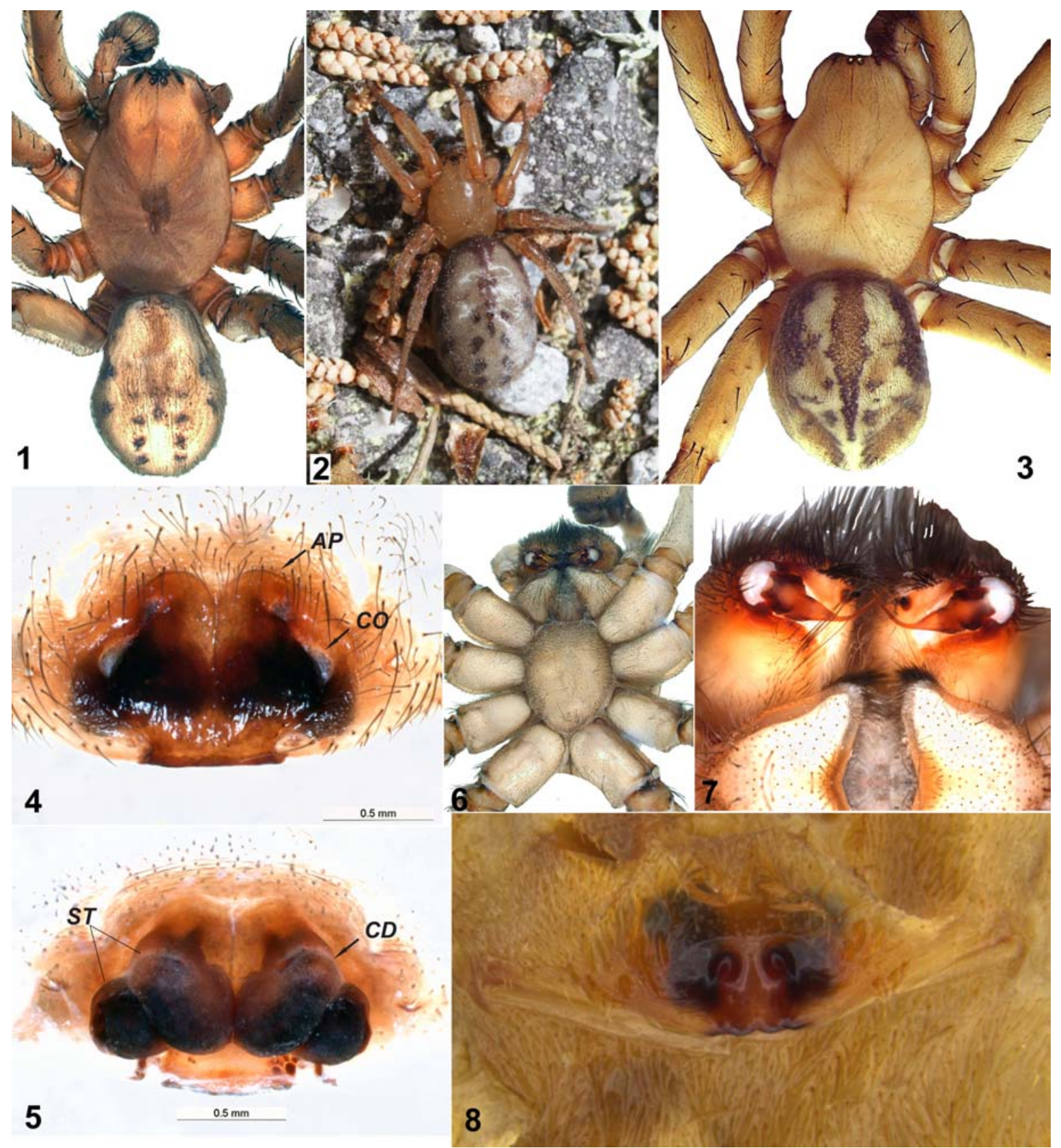

Figs 1-8. Lachesana bayramgocmeni sp.n. (1-2,4-7) and L. blackwalli $(3,8) .1,3$ - male habitus, dorsal; 2 - female habitus, dorsal; 4, 8 - epigyne, ventral; 5 - epigyne, dorsal; 6 - male prosoma, ventral; 7 - male chelicerae and gnathocoxae, ventral. Abbreviations: $A P$ - apical pocket; $C D$ - copulatory duct; $C O$ - copulatory opening; $S T$ - spermatheca.

Рис. 1-8. Lachesana bayramgocmeni sp.n. (1-2, 4-7) и L. blackwalli $(3,8) .1,3$ - самец, сверху; 2 - самка, сверху; 4, 8 эпигина, снизу; 5 - эпигина, сверху; 6 - головогрудь самца, снизу; 7 - хелицеры и максиллы, снизу. Сокращения: $A P-$ верхний карман; $C D$ - копулятивный проток; $C O$ - копулятивное отверстие; $S T$ - сперматека.

\section{Taxonomy}

Family Zodariidae Thorell, 1881 Subfamily Lachesaninae Jocqué, 1991

Genus Lachesana Strand, 1932

TYPE SPECIES: Lachesis blackwalli O. Pickard-Cambridge, 1872 .
COMMENTS. Lachesana is the most species-rich genus of the subfamily, with seven named species distributed from Greece east to Kyrgyzstan and south to Egypt [Fomichev, Marusik, 2019; WSC, 2020].

\section{Lachesana bayramgocmeni sp.n.}

Figs. 1-2, 4-7, 9-12, 15.

TYPES. Holotype Ơ', CYPRUS, Lefkoşa Dist., Kalavaç Vill., 

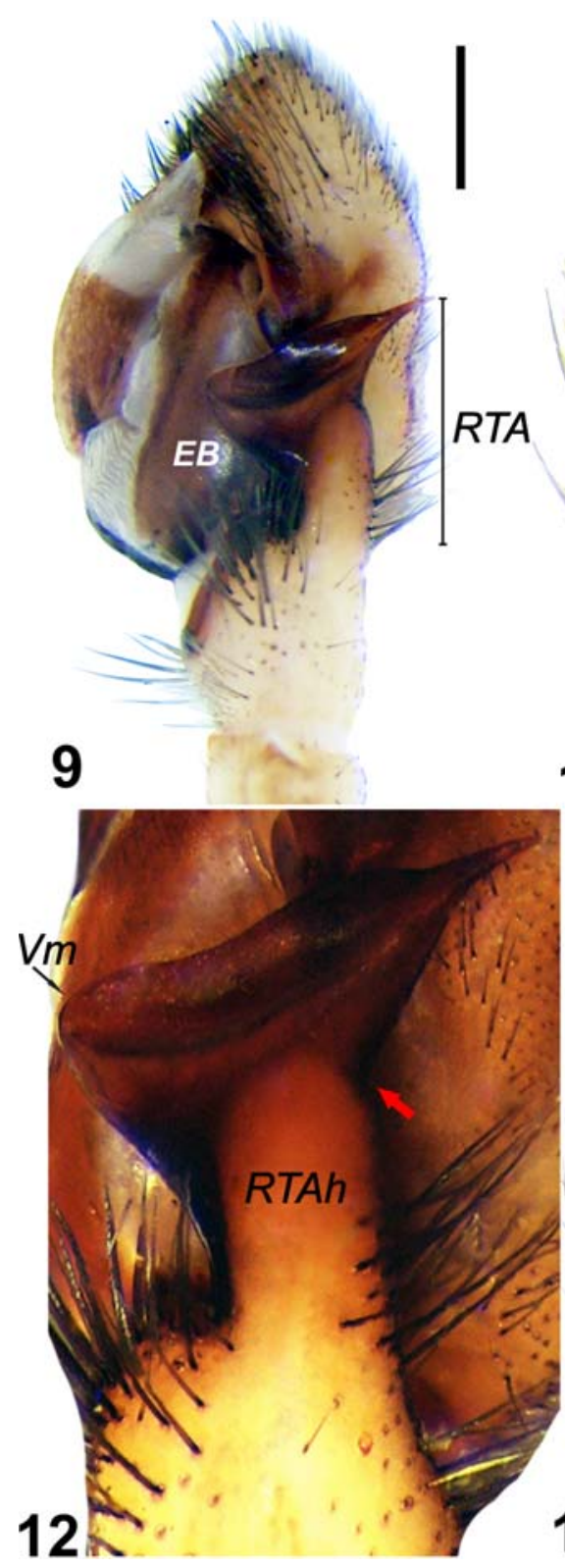
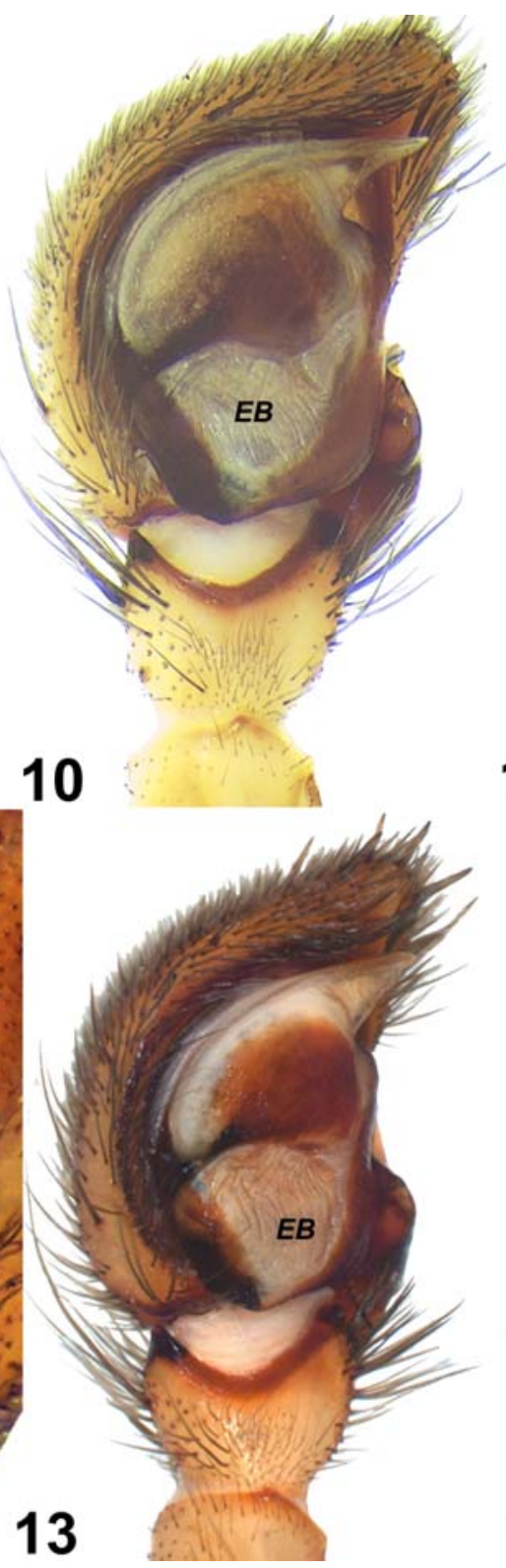
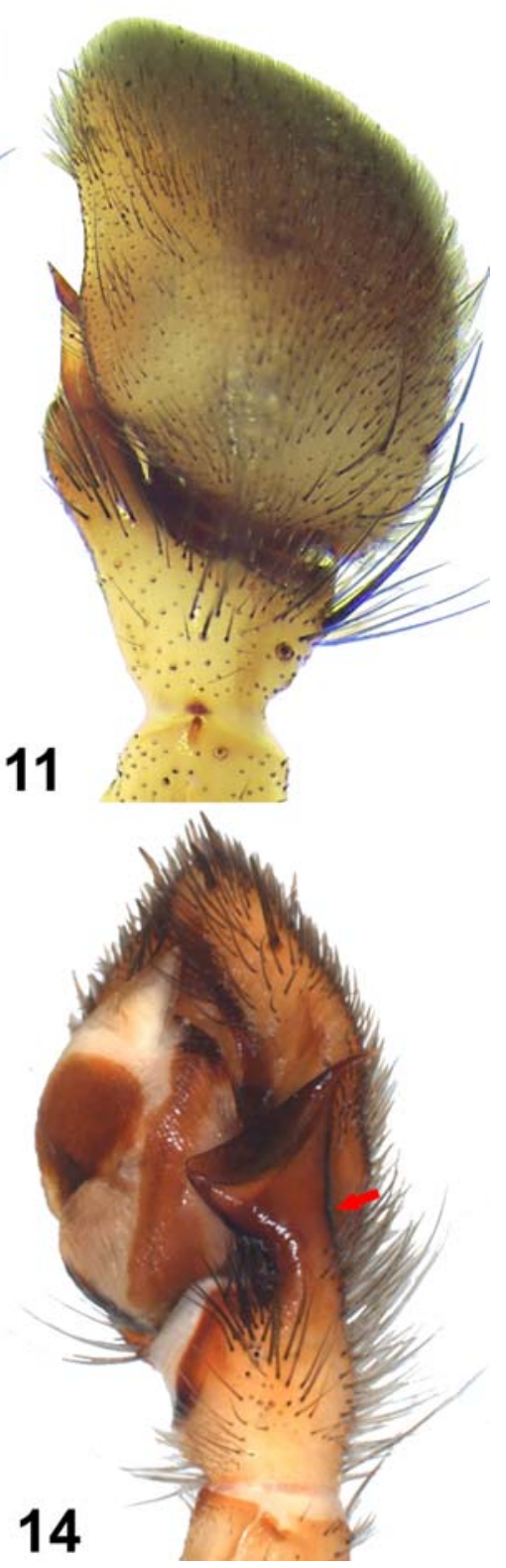

Figs 9-14. Male palp Lachesana bayramgocmeni sp.n. (9-12) and L. blackwalli (13-14). 9, 12, 14 - retrolateral; 10, 13 - ventral; 11 - dorsal. Scale bar: $0.5 \mathrm{~mm}$. Abbreviations: $E B$ — base of embolus; $R T A$ - retrolateral tibial apophysis; RTAh - handle of retrolateral tibial apophysis; $V m$ - ventral margin of deep concavity. Arrows indicate angular differences with RTAh and dorsal margin of $R T A$.

Рис. 9-14. Пальпа самца Lachesana bayramgocmeni sp.n. (9-12) и L. blackwalli (13-14). 9, 12, 14 - ретролатерально; 10, 13 снизу; 11 - сверху. Масштаб: $0.5 \mathrm{~mm}$. Сокращения: $E B$ - основание эмболюса; $R T A$ отросток голени; $R T A h-$ ножка отростка голени; $V m$ - нижний край глубокой впадины. Стрелки показывают угловую разницу между RTAh и верхним краем $R T A$.

Alevkayas1 Area, $35^{\circ} 17^{\prime} 06^{\prime \prime} \mathrm{N} 33^{\circ} 31^{\prime} 41^{\prime \prime}$ E, $630 \mathrm{~m}, 15.09 .2017-$ 13.01.2018, leg. K.B. Kunt \& S. Gücel.

Paratypes: 1 + , Girne Dist., Lapta, Servili Tepe, $35^{\circ} 19^{\prime} 36.90^{\prime \prime}$ N 330' $55.40^{\prime \prime}$ E, $753 \mathrm{~m}, 25.03 .2018$, leg. S. Gücel; 1 ○'

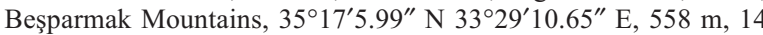
$.01 .2018-22.03 .2018$, leg. K.B. Kunt \& S. Gücel. All types are deposited in CHNM.

ETYMOLOGY. The specific epithet is a patronym, honoring a colleague, a late Cypriot zoologist, Professor Dr. Bayram Göçmen (1965-2019).

DIAGNOSIS. Males of Lachesana bayramgocmeni sp.n. are similar to those of L. blackwalli. However, these two species differ mainly by the shape of tibial apophysis (cf. Figs 12 and 14). The tibial apophysis of the new species has a broader handle $(0.25$ times $)$ and more rounded tip. The ventral margin of the deep concavity of the tibial apophysis is more rounded in L. bayramgocmeni sp.n. (Fig. 12). Females of L. bayramgocmeni sp.n. can be easily distinguished from those of L. blackwalli by the more widely spaced copulatory openings and by their shape as well as by doublelobed receptacles (vs. not doubled in L. blackwalli).

Measurements (holotype $\sigma^{7} /$ paratype + ): Carapace 5.70/ 6.00 long, 4.10/4.20 wide; abdomen: 5.00/5.25 long; ALE: 
Table 1. Length of leg segments in Lachesana bayramgocmeni sp.n. (holotype $\sigma^{\top} /$ paratype ${ }_{+}$). Таблица 1. Длина членикоа ног Lachesana bayramgocmeni sp.n. (голотип О / паратип +).

\begin{tabular}{|c|c|c|c|c|c|c|}
\hline Leg & F & P & T & Mt & Ta & Total \\
\hline I & $5.00 / 5.25$ & $2.00 / 2.30$ & $4.00 / 3.95$ & $3.50 / 3.40$ & $2.50 / 2.60$ & $17.00 / 17.50$ \\
\hline II & $4.60 / 4.50$ & $2.00 / 1.90$ & $3.70 / 3.55$ & $3.50 / 3.40$ & $2.50 / 2.50$ & $16.30 / 15.85$ \\
\hline III & $4.00 / 3.85$ & $2.00 / 1.90$ & $2.70 / 2.60$ & $4.80 / 4.65$ & $2.70 / 2.50$ & $16.20 / 15.50$ \\
\hline IV & $5.20 / 5.10$ & $2.00 / 1.90$ & $3.40 / 3.30$ & $6.50 / 5.80$ & $3.40 / 2.70$ & $20.50 / 18.80$ \\
\hline
\end{tabular}

Table 2. Leg spination in Lachesana bayramgocmeni sp.n. (holotype $\sigma^{7}$ ). Таблица 2. Вооружение ног Lachesana bayramgocmeni sp.n. (голотип О?).

\begin{tabular}{|c|c|c|c|c|c|c|}
\hline Leg & F & P & T & Mt & Ta & Total \\
\hline I & $\mathrm{d} 6 \mathrm{p} 5 \mathrm{r} 4$ & $\mathrm{p} 1$ & $\mathrm{p} 5 \mathrm{r} 1 \mathrm{v} 8$ & $\mathrm{p} 2 \mathrm{r} 2$ & $\mathrm{v} 18$ & 52 \\
\hline II & $\mathrm{d} 5 \mathrm{p} 5 \mathrm{r} 5$ & $\mathrm{p} 1$ & $\mathrm{p} 5 \mathrm{v} 10$ & $\mathrm{p} 3 \mathrm{v} 10$ & $\mathrm{v} 14$ & 58 \\
\hline III & $\mathrm{d} 5 \mathrm{p} 5 \mathrm{r} 5$ & $\mathrm{~d} 1 \mathrm{p} 1 \mathrm{r} 2$ & $\mathrm{~d} 2 \mathrm{p} 3 \mathrm{v} 6$ & $\mathrm{~d} 2 \mathrm{p} 3 \mathrm{r} 4 \mathrm{v} 8$ & $\mathrm{v} 16$ & 63 \\
\hline IV & $\mathrm{d} 6 \mathrm{r} 10$ & $\mathrm{~d} 1 \mathrm{p} 1 \mathrm{r} 2$ & $\mathrm{~d} 2 \mathrm{p} 3 \mathrm{v} 6$ & $\mathrm{~d} 2 \mathrm{p} 3 \mathrm{r} 3 \mathrm{v} 10$ & $\mathrm{v} 16$ & 65 \\
\hline
\end{tabular}

0.23/0.24; AME: 0.23/0.24; PLE: 0.18/0.20; PME: 0.14/ 0.15; AME-AME: 0.10/0.11; AME-PME: 0.08/1.00; PMEPME: $0.12 / 0.13$.

DESCRIPTION. Carapace yellowish-brown (Figs 1-2). Eyes well developed, aligned in two rows. Both rows procurved. Sternum oval, surface covered with short black setae (Fig. 6). Gnathocoxae, labium, and sternum yellowish brown. Gnathocoxae 2 times longer than labium. Tips of gnathocoxae with black setae in form of tuft (Fig. 7). Male chelicerae with modified fangs: triangular at base, with tips recurved anteriorly and sharply tapering from their middle part to tip (Fig. 7)

Abdomen yellowish, dorsally with brownish lanceolate pattern in anterior half and 5 pairs of black spots spread more posteriorly, symmetrically and laterally of midline (Figs 1-2).

Legs yellowish brown. Anterior and posterior parts of coxae slightly darker than other segments. Leg covered with short black setae, denser on dorsal surfaces of patellae and tibiae. Legs with numerous spines. Number of spines and their arrangement vary between opposite legs of the same leg pair. Length of leg segments as in Table 1. Leg spination as in Table 2 .

Male palp as in Figs. 9-12. Femur long, a little shorter than tibia+cymbium. Patella longer than tibia. Tibial apophysis with a distinct handle and a deep concavity. Dorsal part of tibial apophysis jagged and extends to half of the cymbium anteriodorsally. Cymbium nearly 1.7 times longer than wide, with 8-10 strong spines of different length. Base of embolus strongly chitinized prolaterally, other parts with longitudinal wrinkles. Filamentous embolus blackish, lying in the white triangular conductor.

Epigyne as in Figs. 4-5. Epigyne about 1.5 times wider than long, consists of two ear-shaped, chitinous plates, separated by a deep suture vertically continued to the middle of the epigyne. Sides of epigynal plate curved. Anterior pockets strongly sinuous. Anterior part of copulatory ducts swollen and distinct. Copulatory openings situated in the lateral parts of epigyne. Spermathecae swollen, well separated and double lobed.

DISTRIBUTION. Cyprus. Known only from the type series localities.

Lachesana blackwalli (O. Pickard-Cambridge, 1872) Figs 3, 8, 13-14, 15.

Lachesis blackwalli: O. Pickard-Cambridge, 1872: 266, pl. 13, f. $5\left(O^{\top}+\right)$.
Lachesana blackwalli: Levy, 1990: 333, f. 1-6, 8-14 (О7o).

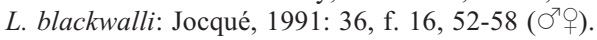

L. blackwalli: Thaler, Knoflach, 2004: 41, f. 4, 12, 14, 17, 19, 22, $25\left(O^{7}\right)$

MATERIAL EXAMINED: TURKEY (all in ETZM): $1 \sigma^{\top}$, Muğla Prov., Seydikemer Dist., Girdev Plateau, $36^{\circ} 44^{\prime}$ N $29^{\circ} 37^{\prime} \mathrm{E}$, 2150 m, 14.08.2005, leg. E.A. Yağmur. $1 \sigma^{\top}$, Manisa Prov., Spil

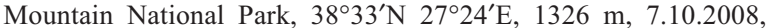
leg. E.A. Yağmur. İzmir Prov.: 3 juv., Buca Dist., Kaynaklar Vill, $38^{\circ} 21^{\prime} \mathrm{N} 27^{\circ} 17^{\prime} \mathrm{E}, 377 \mathrm{~m}, 27.02 .2010$, leg. E.A. Yağmur 1 ऊ', Bergama Dist., Güneșli Vill., 39 $9^{\circ} 19^{\prime} \mathrm{N} 27^{\circ} 8^{\prime} \mathrm{E}, 578$ m, 5.05.2013, leg. E.A. Yağmur. $1 \mathrm{O}^{\prime \prime}$, Karaman Prov., Sertavul Pass, $36^{\circ} 51^{\prime} 24^{\prime \prime} \mathrm{N}$ $33^{\circ} 17^{\prime} 01^{\prime \prime}$, 1435 m, September-December 2010, leg. K.B. Kunt, R.S. Özkütük \& E.A. Yağmur. Antalya Prov.: $1 \sigma^{7}$, Alanya Dist., Taşatan Plateau, $36^{\circ} 40^{\prime} \mathrm{N} 32^{\circ} 10^{\prime} \mathrm{E}, 1186 \mathrm{~m}$, pitfall traps, $14.07-$ 12.09.2011, leg. K.B. Kunt \& R.S. Özkütük; 1 ᄁ', Alanya Dist., Elikesik Vill., 36 $33^{\prime} 55^{\prime \prime} \mathrm{N} 31^{\circ} 55^{\prime} 31^{\prime \prime} \mathrm{E}, 36 \mathrm{~m}, 17.01 .2016-1.04$. 2017, leg. K.B. Kunt. Eskișehir Prov.: $2 \sigma^{\top} \sigma^{7}$, Tepebaşı Dist., Tandir Vill., $39^{\circ} 56^{\prime} \mathrm{N} 30^{\circ} 29^{\prime} \mathrm{E}, 1145 \mathrm{~m}, 14.08 .2012$, leg. F. Altunsoy; 8 ○ $^{\top}$, Odunpazarı Dist., Yukarı Kalabak Vill., 39³0’ N 30 24’E, 17.02-2.05.2013, leg. R.S. Özkütük; $5 \sigma^{\top} \sigma^{\top}$, Isparta Prov., Atabey Dist., Hidirlık Area, 37 56 ' N 30³9’ E, 1033 m, 27.10.2016, leg. G. Aydın. CYPRUS: $1 \sigma^{7}$ (ZMMU), Karpaz Peninsula, Dipkarpaz Vill., 35 $40^{\prime} \mathrm{N} 34^{\circ} 34^{\prime} \mathrm{E}, 2 \mathrm{~m}, 16.01 .2018-22.03 .2018$, leg. K.B. Kunt \& S. Gücel.

DISTRIBUTION. Lachesana blackwalli is the most studied species of the genus (see Levy, 1990; Jocqué, 1991; Thaler, Knoflach, 2004). The species is known from Israel, Cyprus, Lebanon, Greece (Crete and North Aegean islands), and Turkey (Fig. 15) [WSC, 2020].

Levy [1990] mentions that L. blackwalli possibly exists in Syria, since the Israeli populations of the species could be found in a wide range of habitats from cold and humid mountainous areas to the semi-desert regions. Although we did not find the species during our field trips at the TurkeySyria border, a previous record of L. blackwalli by Jocqué [1991] from the Syrian border may support Levy's suggestion [1990]. During our field studies, we collected L. blackwalli specimens from almost sea level within the arid Mediterranean maquis and up to the high mountain habitats around 2,000 m (Fig. 15).

Thaler \& Knoflach [2004] recorded this species from the coastal part of Baf City, which is located the western side of the Cyprus. Recently, Bosmans et al. [2019] also recorded L. blackwalli in their checklist on the spiders of Cyprus from Baf, Girne, Gazi Mağusa and Limasol cities. Our single record is from Cape Andreas which is the easternmost point of the island and is very close to the sea. 


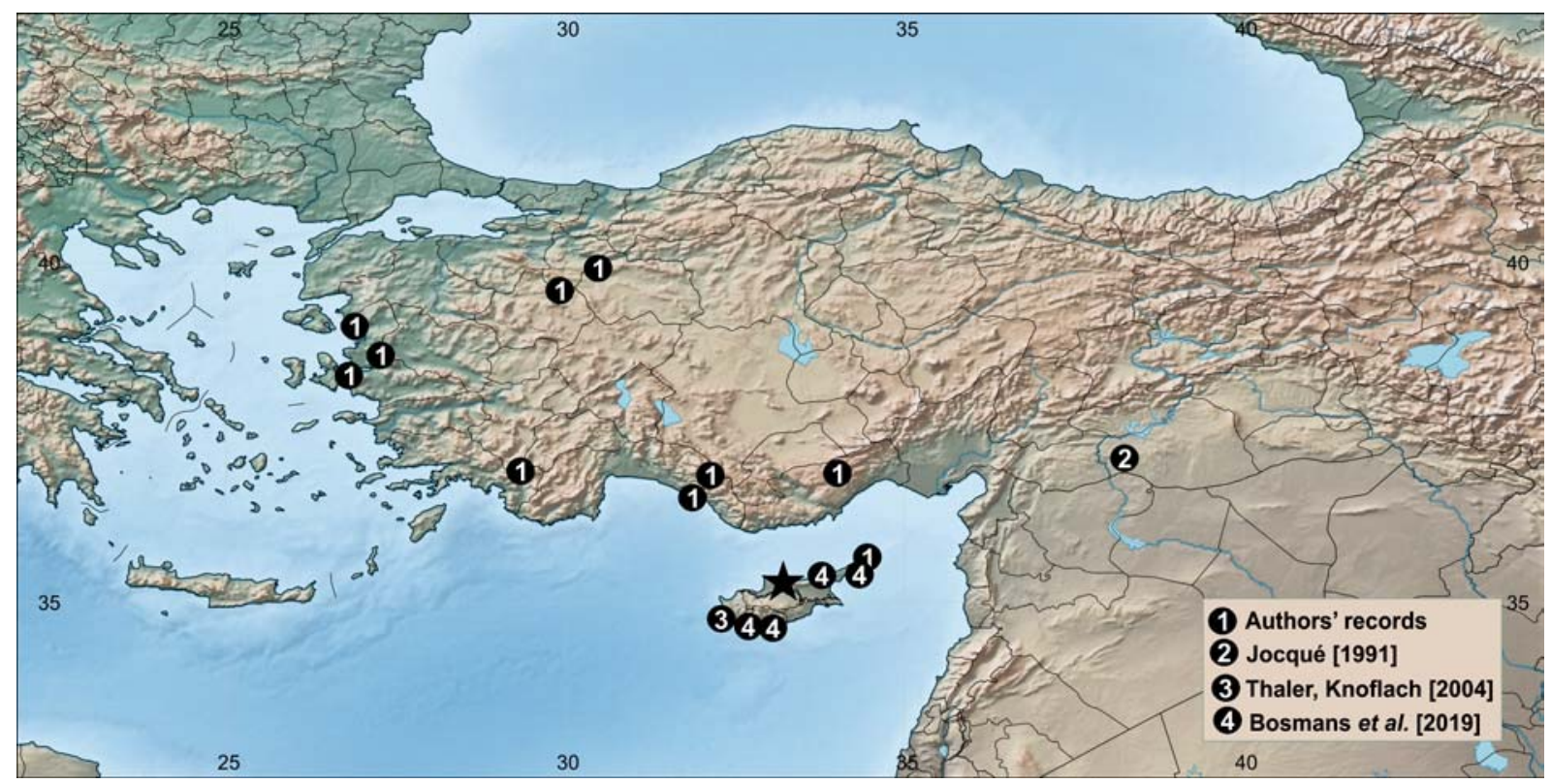

Fig. 15. Collecting localities of Lachesana blackwalli $(\mathbf{O})$ and L. bayramgocmeni sp.n. ( $\star$ ).

Рис. 15. Места сборов Lachesana blackwalli ( ) и L. bayramgocmeni sp.n. ( $\star$ ).

\section{Acknowledgments}

This study was supported by the Near East University, Scientific Research Projects Commission under the grant no. BAP 201-2015. We are very grateful to Yuri M. Marusik (Magadan, Russia) and Sergei Zonstein (Tel Aviv, Israel) for their valuable comments on the first draft of this paper. We thank Zoë Simmons (Oxford, UK) for providing a photograph of epigyne of L. blackwalli from the exotic Araneae collection of O. Pickard-Cambridge. We are also thankful to Wayne Fuller (Nicosia, Cyprus) for editing the English of the manuscript. The English of the final draft was kindly checked by Victor Fet (West Virginia, USA).

\section{References}

Bosmans R., Van Keer J., Russell-Smith A., Hadjiconstantis M., Komnenov M., Bosselaers J., Huber S., McCowan D., Snazell R., Decae A., Zoumides C., Kielhorn K.H., Oger P. 2019. Spiders of Cyprus (Araneae). A catalogue of all currently known species from Cyprus // Newsletter of the Belgian Arachnological Society. Vol. 34. P.1-173.

Jocqué R. 1991. A generic revision of the spider family Zodariidae (Araneae) // Bulletin of the American Museum of Natural History. Vol.201. P.1-160.
Kulczyński W. 1908. Fragmenta arachnologica. X // Bulletin International de l'Académie des Sciences de Cracovie. P.49-86.

Levy G. 1990. Spiders of the genus Lachesana and a new storenoid genus from Israel (Araneae: Zodariidae) // Zoological Journal of the Linnean Society. Vol.98. P.327-362.

Fomichev A.A., Marusik Yu.M. 2019. A new species of Lachesana Strand, 1932 (Aranei: Zodariidae) from southern Kazakhstan // Arthropoda Selecta. Vol.28. No.4 P.556-561. doi:10.15298/ arthsel.28.4.08

Pickard-Cambridge O. 1872. General list of the spiders of Palestine and Syria, with descriptions of numerous new species, and characters of two new genera // Proceedings of the Zoological Society of London. Vol.40. No.1. P.212-354.

Reimoser E. 1927. Spinnen aus Pulu Berhala // Miscellanea Zoologica Sumatrana. Vol.21. P.1-4.

Simon E. 1873. Aranéides nouveaux ou peu connus du midi de l'Europe. (2e mémoire) // Mémoires de la Société Royale des Sciences de Liège. Vol.2. No.5. P.187-351.

Simon E. 1893. Histoire naturelle des araignées. Paris. Vol.1. P.257488.

Thaler K., Knoflach B. 2004. A new Lachesana species from Greece and additional records from the Near East (Arachnida, Araneae, Zodariidae) // Bulletin of the British Arachnological Society. Vol.13. Pt.2. P.41-46.

Responsible editor Yu.M. Marusik 